\title{
EFFECT OF SODIUM ION ON LEVELS OF CYCLIC ADENOSINE 3',5-MONOPHOSPHATE IN GUINEA PIG CEREBRAL SLICES
}

\author{
Iwao YAMAMOTO, Naomasa MIKI*, Shigeru KONDO \\ and Shiro KAKIUCHI** \\ Department of Pharmacology, Dental School and ${ }^{* *}$ Institute of Higher \\ Nervous Activity, Osaka University, Osaka 530, Japan
}

Accepted December 19, 1977

\begin{abstract}
Accumulation of cyclic AMP was studied in guinea pig cerebral slices when $\mathrm{Na}^{+}$levels in the bathing medium were varied or agents which affect tissue $\mathrm{Na}^{+}$content were added. When $\mathrm{NaCl}$ was gradually replaced with Tris- $\mathrm{HCl}$ or choline chloride, cyclic AMP formation was progressively enhanced. When $\mathrm{Na}^{+}$was below $30 \mathrm{mM}$, cyclic AMP formation reached the maximum (approximately 30 fold), but this incrcment was not blocked by tetrodotoxin. The stimulatory effect of high $\mathrm{K}^{+}$was nearly linear over $120 \mathrm{mM}$ and became much more prominent when $\mathrm{Na}^{+}$was decreased to $30-40 \mathrm{mM}$ in the bathing medium. The effect of high $\mathrm{K}^{+}$also was not blocked by tetrodotoxin. Ouabain $\left(10^{-4} \mathrm{M}\right)$, electrical pulses and glutamate $\left(5 \times 10^{-3} \mathrm{M}\right)$, each stimulated cyclic AMP formation about $17-, 7-$ and 5 -fold, respectively. Tetrodotoxin $\left(2 \times 10^{-6} \mathrm{M}\right)$ completely blocked the effects of electrical pulses and partially blocked the effects of glutamate and ouabain. It is suggested that the increase of cyclic AMP in cerebral cortical slices may be related to the decrease in $\mathrm{Na}^{+}$gradient across the cell membrane.
\end{abstract}

In slices of guinea pig cerebral cortex, the accumulation of adenosine $3^{\prime}, 5^{\prime}$-monophosphate (cyclic AMP) appears to be stimulated by several factors including: (i) stimulation by biogenic amines (1), (ii) membrane depolarizing agents (2), (iii) adenine ribonucleotides (3) and some amino acides (4). We report herein the relationship between sodium ion and cyclic AMP formation in guinea pig cerebral slices and discuss the possibility that the formation of cyclic AMP is determined by the concentration gradient of sodium ion across the cell membrane.

\section{MATERIALS AND METHODS}

Hartley guinea pigs weighing 250-300 gms were decapitated and the cerebri removed and immersed in ice cold incubation medium. The cortex $(0.2-0.3 \mathrm{~mm}$ thick) was separated and chopped tissue from 2-3 animals was transferred into a beaker containing $50 \mathrm{ml}$ of incubation medium. Preincubation was carried out for $30 \mathrm{~min}$ at $37^{\circ} \mathrm{C}$. This preincubation was sufficient to reduce the level of cyclic AMP to a stable minimum. After preincubation, the tissue was divided into 8-12 portions, estimated to contain between 3-6 mg of protein and each portion was transferred into $10 \mathrm{ml}$ of fresh medium in a set of glass centrifuge tubes.

* Present Address: Department of Pharmacology, Kyoto Prefectural University of Medicine, Kyoto 602, Japan 
Incubation was then carricd out for ten min at $37^{\circ} \mathrm{C}$ in the presence or absence of various agents. After incubation, the medium was decanted and 1-2 $\mathrm{nl}$ of ice cold $10 \%$ trichloroacetic acid was added and the tube was immersed in dry-ice acetone. The incubation medium ( $\mathrm{pH} 7.5$ ) consisted of $120 \mathrm{mM} \mathrm{NaCl}, 5 \mathrm{mM} \mathrm{KCl}, 2 \mathrm{mM} \mathrm{CaCl}, 2 \mathrm{mM} \mathrm{KH}_{2} \mathrm{PO}_{i}$, $2 \mathrm{mM} \mathrm{MgSO}_{4}, 40 \mathrm{mM}$ Tris- $\mathrm{HCl}$ buffer and $10 \mathrm{mM}$ glucose. The solution was gassed during all incubation procedures with oxygen. The control values of cyclic AMP contents observed in slices incubated in Tris-HCl buffer were more stable and lower than that in bicarbonate buffer. The frozen tissue was homogenized in a glass homogenizer after the addition of $1.0 \mathrm{p}$ mole of cyclic $\left[{ }^{3} \mathrm{H}\right]$ AMP (about $12,000 \mathrm{cpm}$ ) for the estimation of recovery. The homogenate was centrifuged at room temperature for $20 \mathrm{~min}$ at $2,000 \mathrm{rpm}$. One $\mathrm{ml}$ of $1 \mathrm{~N}$ $\mathrm{NaOH}$ was added to the precipitate and protein was estimated by the method of Lowry et al (5). The supernatant was extracted 5 times with 5 volumes of ether which had been saturated with water. The residual ether was evaporated at $55^{\circ} \mathrm{C}$ with a stream of air. Each extract was applied to a column packed with one gram of basic aluminum oxide (6) and eluted with $5 \mathrm{ml}$ of distilled water. The eluate fraction was dried with a rotary evaporator at $55^{\circ} \mathrm{C}$ and the flask was extracted with $300 \mu$ of water. Ten $/ 1$ of sample was used for assay of cyclic AMP and 50,1 of sample was used for estimating recovery. The average recovery of cyclic AMP was about $60 \%$.

Cyclic AMP was estimated by a modification of the method of Gilman (7). Binding protein was purified from rabbit muscle by the method of Reiman et al (8).

Electrical pulses were administrated to the cerebral cortex slices according to the method of Kakiuchi et al (9) with a slight modification. Twelve volt condenser pulses were applied for $10 \mathrm{~min}$ with a time constant of $0.4 \mathrm{msec}$ and a frequency of $100 \mathrm{Hertz}$.

Cyclic AMP (Na salt) was purchased from Kohjin Co., tetrodotoxin from the Sankyo Co., and basic aluminum oxide from Merck Chemical Co. Cyclic $\left[{ }^{3} \mathrm{H}\right]$ AMP $(24.1 \mathrm{Ci} / \mathrm{m}$ mole) was purchased from New England Nuclear.

\section{RESULTS}

\section{Effect of sodium ion on cyclic AMP formation}

When $\mathrm{NaCl}$ in the Krebs Ringer solution was completely replaced by $\mathrm{Tris}-\mathrm{HCl}(\mathrm{pH}$ 7.5) or choline chloride, cyclic AMP accumulation in the slices was greatly increased (Fig. 1). In Tris-Ringer ( $\mathrm{Na}^{+}$-free), cyclic AMP levels were twice as high as in choline-Ringer $\left(\mathrm{Na}^{+}-\right.$ free). When $\mathrm{NaCl}$ was gradually added to the bathing medium (Tris-Ringer), cyclic AMP formation began to decrease above $10 \mathrm{mM} \mathrm{NaCl}$ and reached the control level when $\mathrm{NaCl}$ exceeded $30 \mathrm{mM}$. In choline-Ringer ( $\mathrm{Na}^{+}-$free), the level of cyclic AMP formation decreased to the control level when $\mathrm{NaCl}$ exceeded $20 \mathrm{mM}$.

Time course of cyclic AMP formation in $\mathrm{Na}^{+}$-free medium

Cyclic AMP formation reached almost the maximal level $2 \mathrm{~min}$ after changing to a $\mathrm{Na}$-free medium. Cyclic AMP content in these slices began to decrease after $25 \mathrm{~min}$ (Fig. 2). 
Effect of sodium and potassimm ions on cyclic AMP formation

When $\mathrm{KCl}$ was gradually added to the Krebs Ringer solution (up to concentrations of $120 \mathrm{mM}$ ), cyclic AMP formation lincarly increased (Fig. 3). However, when $\mathrm{NaCl}$ in high $\mathrm{K}^{+}$(46 mM) Ringer was gradually replaced with Tris-HCl, accumulation of cyclic AMP

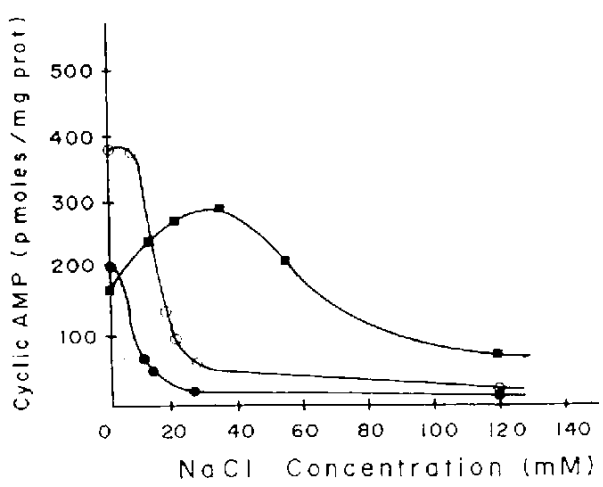

FIG. 1. Effects of sodium and potassium ions on cyclic AMP accumulation. Chopped slices of cerebral cortex were preincubated in normal Ringer's solution. The preincubated slices were transferred into the fresh medium with a varying composition of ions and then incubated for an additional $10 \mathrm{~min}$. In Tris-Ringer ( $\mathrm{Na}{ }^{\prime}$-free) or choline-Ringer $\left(\mathrm{Na}^{+}-\mathrm{free}\right), \mathrm{NaCl}$ was completely replaced by Tris or cholinium ions. In the dose response curve, $\mathrm{NaCl}$ was gradually added to $\mathrm{Na}$-free Ringer up to $60 \mathrm{mM}$ and the normal Ringer was used at a concentration of $120 \mathrm{mM} \mathrm{NaCl}$. High $\mathrm{K}^{-}(46 \mathrm{mM})$ Ringer was made by adding $\mathrm{KCl}$ to the normal Ringer. $)$ Tris-Ringer $\left(\mathrm{Na}^{+}\right.$-free); choline-Ringer $\left(\mathrm{Na}^{+}\right.$-free); $\mathrm{high} \mathrm{K}^{+}(46 \mathrm{mM})$ Ringer

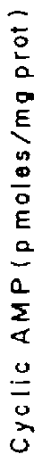

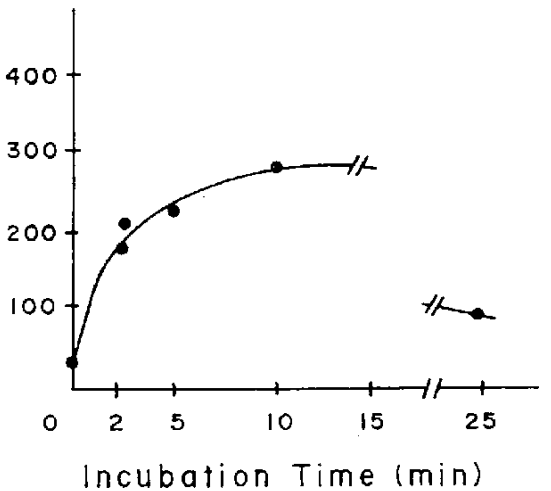

Fig. 2. Time course of cyclic AMP accumulation in slices incubated in Tris-Ringer $\left(\mathrm{Na}^{+}\right.$-free). After preincubation of chopped slices in normal Ringer's for 30 min, the slices were transferred to TrisRinger $\left(\mathrm{Na}^{-}\right.$-free $)$and incubated as shown.

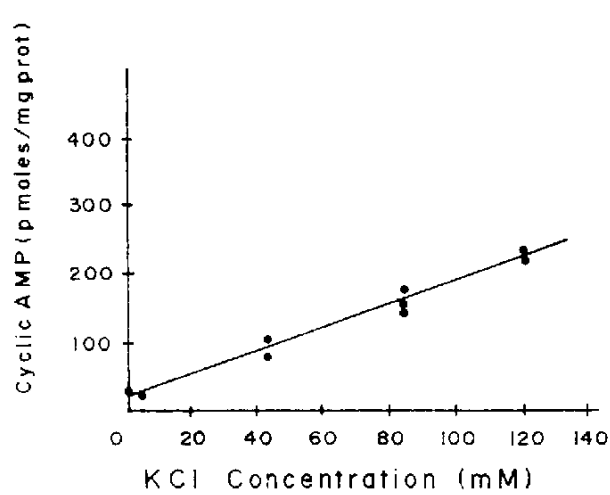

Fig. 3. Effect of potassium ion on cyclic AMP accumulation. Preincubation and incubation were identical to those in Fig. 1. In the dose response curve, $\mathrm{KCl}$ was gradually added to normal Ringer's up to $120 \mathrm{mM}$. $\mathrm{KCl}$ and $\mathrm{KH}_{2} \mathrm{PO}_{4}$ were completely replaced by Tris and $\mathrm{NaH}_{2} \mathrm{PO}_{4}$ at zero $\mathrm{KCl}$. 
in slices began to increase even more than was observed with the addition of $\mathrm{KCl}$ to the normal Ringers and reached the maximum at $\mathrm{Na}^{+}$concentrations of approximately $30 \mathrm{mM}$ (Fig. 1). This maximal value was less than that found in slices incubated in Tris-Ringer $\left(\mathrm{Na}^{+}-\right.$free) solution. However, the complete onission of $\mathrm{NaCl}$ from high $\mathrm{K}+$ Ringer somewhat reduced the levels of cyclic AMP (Fig. 1).

\section{Effect of tetrodotoxin on cyclic AMP formation}

When electrical stimulation was applied to a layer of cerebral cortex slice, cyclic AMP levels increased about 5-7 times above the level found in the control (Table 1). The effect of electrical stimulation was completely blocked by $2 \times 10^{-6} \mathrm{M}$ tetrodotoxin. However, increases in cyclic AMP levels associated with $\mathrm{Na}^{+}$-free Ringer or high $\mathrm{K}^{+}$Ringer were not prevented by tetrodotoxin. The effects of ouabain and glutamate were partially blocked by tetrodotoxin (Table 1).

TABLE 1. Effect of tetrodotoxin on cyclic AMP content

\begin{tabular}{lc}
\hline & $\begin{array}{c}\text { Cyclic AMP } \\
\text { (p moles/mg protein) }\end{array}$ \\
Control & $14.0 \pm 2$ \\
Control-tetrodotoxin $\left(2 \times 10^{-6} \mathrm{M}\right)$ & $10.0 \pm 2$ \\
Electrical pulses (E.P.) & $95.5 \pm 10$ \\
E.P. + tetrodotoxin & $13.5 \pm 3$ \\
Tris-Ringer $\left(\mathrm{Na}^{-}\right.$-free) & $290.5 \pm 25$ \\
Tris-Ringer $\left(\mathrm{Na}^{+}\right.$-free) + tetrodotoxin & $302.5 \pm 28$ \\
High $\mathrm{K}^{+}\left(86 \mathrm{mM}^{-}\right)$ & $144.4 \pm 15$ \\
High $\mathrm{K}^{+}-$tetrodotoxin & $141.2 \pm 14$ \\
Ouabain $\left(10^{-4} \mathrm{M}\right)$ & $245.0 \pm 20$ \\
Ouabain - tetrodotoxin & $120.5 \pm 11$ \\
Glutamate $\left(5 \times 10^{-3} \mathrm{M}\right)$ & $68.6 \pm 7$ \\
Glutamate- tetrodotoxin & $47.0 \pm 5$ \\
\hline
\end{tabular}

A layer of cerebral cortex slice was stimulated by 12 volt condenser pulses, at a time constant of $0.4 \mathrm{msec}$ and a frequency of $100 \mathrm{Hertz}$. All samples were incubated for $10 \mathrm{~min}$. Each value represents the mean $\perp$ S.D. obtained from four separate experiments.

TABLE 2. Effect of lithium ion on cyclic AMP content

\begin{tabular}{lcc}
\hline & $\begin{array}{c}\mathrm{NaCl}(120 \mathrm{mM}) \\
\text { Cyclic AMP (p moles }\end{array}$ & $\mathrm{LiCl}(120 \mathrm{mM}$ protein) \\
\hline Control & $11.5 \pm 2$ & $14.0 \pm 2$ \\
Electrical pulses & $56.0 \pm 3$ & $12.5 \pm 2$ \\
Adenosine $\left(2 \times 10^{-4} \mathrm{M}\right)$ & $202.0 \pm 11$ & $9.5 \pm 2$ \\
High K$^{+}(86 \mathrm{mM})$ & $135.0 \pm 14$ & $9.0 \pm 2$ \\
Histamine $\left(5 \times 10^{-4} \mathrm{M}\right)$ & $53.0 \pm 3$ & $7.5 \pm 1$ \\
\hline
\end{tabular}

$\mathrm{LiCl}$ completely replaced $\mathrm{NaCl}$ in $\mathrm{Li}^{+}-\mathrm{Ringer}$ solution. Samples were incubated for $10 \mathrm{~min}$. Each value represents the mean $=S$.D. obtained from four separate experiments. 


\section{Effect of lithitum chloride on cyclic AMP accumulation}

Lithium can replace $\mathrm{Na}^{+}$in the formation of the action potential (10). The accumulation of cyclic AMP was not enhanced by electrical stimulation for $10 \mathrm{~min}$ in a $\mathrm{Li}^{+}$Ringer solution (Table 2). In addition, the effects of adenosine, high $\mathrm{K}^{+}$and histamine were completely prevented by $\mathrm{Li}^{+}$-Ringer.

\section{DISCUSSION}

The concentration of cyclic AMP in cerebral cortex slices was greatly increased when $\mathrm{Na}^{+}$in the bathing medium was replaced by Tris or cholinium ions. Tris-Ringer ( $\mathrm{Na}^{+}-$free) was more effective than choline-Ringer ( $\mathrm{Na}^{+}-$free) in this respect. Hypertonic cholineor Tris-Ringer ( $\mathrm{Na}^{+}$-free) made up with the addition of $50 \mathrm{mM}$ sucrose also showed similar stimulatory effects on cyclic AMP accumulation in cerebral slices. Shimizu and Daly (11, 12) also have reported that complete omission of $\mathrm{Na}^{+}$from the Krebs-Ringer medium and replacement with other cations, such as cholinium, tetramethylammonium and $\mathrm{NH}_{4}$ or with sucrose causes an enhanced accumulation of cyclic AMP. This stinulatory effect is not seen with cholinium or tetramethylammonium ions in the presence of $25 \mathrm{mM} \mathrm{NaCl}$ (11). We also observed that the effect of $\mathrm{Na}^{+}$-free Ringer cannot be attributable to the presence of either Tris or cholinium ions in the bathing medium, since increased accumulation of cyclic AMP was abolished by the addition of $\mathrm{NaCl}$ above $30 \mathrm{mM}$ in the presence of these cations. Shimizu et al (2) also suggested that the formation of cyclic AMP in the brain slices is greatly stimulated by depolarizing agents such as ouabain and veratridine and high $\mathrm{K}^{+}$medium. The effect of the $\mathrm{Na}^{+}$-free Ringer observed in this study, however, cannot be explained by a depolarizing mechanism, since it has been reported that $\mathrm{Na}^{+}$-free Ringer in which $\mathrm{Na}^{+}$is replaced by Tris or cholinium ion does not produce a depolarization in excitable tissues within a short time period, but rather results in a hyperpolarization $(13,14,15)$. Furthermore, hypertonic Ringer $(\mathrm{NaCl}, 225 \mathrm{mM}$ ) had no stimulatory effect on cyclic AMP formation (data was not shown.), though it has been reported that excess $\mathrm{NaCl}$ causes a depolarization $(13,15)$. As shown in Fig. 2, the large increase in cyclic AMP content in slices occurred within 2 min following the reduction in $\mathrm{Na}^{+}$. The data further indicate that the effect of the $\mathrm{Na}^{+}$-free system may be direct, since the metabolic disturbances which take place secondarily in brain slices incubated in $\mathrm{Na}^{+}$-free Ringer are not observed for at least 10 min (10). It is also known that participation of $\mathrm{Na}^{+}$is necessary for the occurrence of the action potential and, that lithium can replace $\mathrm{Na}^{+}$in this process (10). The accumulation of cyclic AMP in slices was not stimulated by electrical pulses in $\mathrm{Li}^{+}$-Ringer in which $\mathrm{Na}^{-}$ was replaced by lithium. Lithium ion itself would be an potent inhibitor of cyclic AMP formation in slices, since histamine and adenosine did not stimulate cyclic AMP accumulation in $\mathrm{Li}^{+}$-Ringer. Dousa and Hetcher (16) have shown that $\mathrm{F}^{-}$sensitive brain adenylate cyclase is directly inhibited by lithium. Lithium ion at high concentrations ( 1 to $50 \mathrm{mM}$ ) also reduces norepinephrine-induced formation of cyclic AMP in rat cerebral cortex slices (17) and histamine-induced formation of cyclic AMP in slices from rabbit cerebral cortcx (17) and rat hypothalamus (18). 
There is also an alternative way to increase the cyclic AMP content in brain stices. Application of electrical pulses to slices or exposure of slices to glutamate resulted in an increase in the cyclic AMP content (Table 1). These treatments are known to increase the intracellular concentration of $\mathrm{Na}^{+}$(19). Interestingly, tetrodotoxin which is known to block the increase of sodium conductance $(20,21)$ inhibited the effect of electrical pulses complately but not the effect of the $\mathrm{Na}^{+}$-free system.

The increase in cyclic AMP content produced by high $\mathrm{K}^{+}$, which increases the intracellular $\mathrm{Na}^{+}$(22) was nearly linear up to $120 \mathrm{mM} \mathrm{K}^{+}$but not as prominent as the metabolic responses or release of biogenic amines produced by high $\mathrm{K}^{+}(23,24)$. When $\mathrm{Na}^{-}$was reduced in high $\mathrm{K}^{+}$Ringer, however, cyclic AMP formation was greatly stimulated. The complete omission of $\mathrm{NaCl}$ from high $\mathrm{K}^{*}(46 \mathrm{mM})$ Ringer somewhat reduced the levels of cyclic AMP. Shimizu and Daly reported similar results with high $\mathrm{K}^{+}(150 \mathrm{mM})$ Ringer (11). Thus the cyclic AMP level in cerebral tissue was shown to increase either when the concentration of $\mathrm{Na}^{+}$in the medium decreased or when the intracellular $\mathrm{Na}^{+}$concentration increased. These observations can be reasonably explained if it is assumed that the concentration of cyclic AMP in the cell is regulated by the sodium ion gradient across the cell nembrane. The active transport of amino acids and sugars across the cell membrane exemplified such a mechanism. Here, the rate of transport is dependent upon the $\mathrm{Na}^{+}$ gradient but independent of intracellular concentrations of $\mathrm{Na}^{+}(25,26)$.

Our conclusion, however, would be compatible with the depolarizing hypothesis proposed by Shimizu and Daly (11), if a depolarization of the cerebral cells can be induced by the decrease in $\mathrm{Na}^{+}$gradient across the ccll membrane, according to an equation reported by Hodgkin and Katz (27).

It has been reported that the effects of both depolarizing agents and adenosine were suppressed by theophylline $(1,3)$. In addition, the effects of depolarizing agents have been attributed to the release of adenosine (12). Since the effect of $\mathrm{Na}^{+}$-free Ringer was also suppressed by theophylline, it is postulated that decrease in the sodium gradient across the cell numbrane may induce a release of adenosine, which in turn stimulates the formation of cyclic AMP.

\section{REFERENCES}

1) KAKILCHI, S. AND RALL, T.W.: Studics on adenosine 3,5-phosphate in rabbit cercbral cortex. Mol. Pharmacol. 4, 379-388 (1968)

2 Shimizl, H., CreyeliNg, C.R. ANd Daly, J.W.: Cyclic adenosine 3',5'monophosphate formation in brain slices; stimulation by batrachotoxin, ouabain, veratridine, and potassium ions. Mol. Pharmacol. 6, 184-188 (1970)

3) SattiN, A. AND RaLl, T.W.: The effect of adenosine and adenine nucleotides on the cyclic adenosine 3',5'phosphate content of guinea pig cerebral cortex slices. Mol. Pharmacol. 6, 13-23 (1970)

4) ShImize, H., ICHIshita, H. AND Odagiri, H.: Stimulated formation of cyclic adenosine 3',5'monophosphate by aspartate and glutamate in cerebral cortical slices of guinea pig. J. biol. Chem. 249, 5955-5962 (1974)

5 Lowry, O.H., Rosebrovgh, N.J., Farr, A.L. and Randall, R.J.: Protein measurement with the Folin phenol reagent. J. biol. Chem. 193, 265-275 (1951) 
6) WHITF, A.A. ANn ZFNSFR, T.V.: Separation of cyclic $33^{\prime}, 5^{\prime}$-nucleotide monophosphates from other nucleotides on aluminum oxide columns: application to the assay of adenylate cyclase and guanylate cyclase. Analyt. Biochem. 41, 372-396 (1971)

7) Gilmax, A.G.: A protein binding assay for adenosine 3',5'-cyclic monophosphate. Proc, nath. Acad. Sci, U.S.A. 67, 305-312 (1970)

8) RemanN, E.M., Walsh, D.A. ANd Krebs, E.G.: Purification and properties of rabbit skeletal muscle adenosine 3',5'-monophosphate-dependent protein kinases. J. biol. Chem. 246, 1986-1995 (1971)

9) Kahiuchi, S., Rall, T.W. and MCllwain, H.: The effect of electrical stimulation upon the accumulation of adenosine 3',5'-phosphate in isolated cerebral tissue. J. Neurochem. 16, 485-491 (1969)

10) Overtox, E.: Beitrage zur allgemeinen Muskel- und Nervenphysiologie. 92, 346-386 (1902)

11) SHmize, H. AND Dal., J.W.: Fffect of depolarizing agents on accumulation of cyclic adenosine 3',5'-monophosphate in cerebral cortical slices. Europ. J. Pharmacol. 17, 240-252 (1972)

12) Daly, J.W.: Cyclic Nucleotides in the Nerrous System, p. 116-122, Plenum Press, New York (1977)

13) Shanes, A.M.: Electrical aspects of physiological and pharmacological action in excitable cells. Pharmacol. Rev. 10, 59-164 (1958)

14) GORviN, A.I.F. AND MARMOR, M.F.: Contribution of the sodium pump and ionic gradients to the membrane potential of a molluscan neuron. J. Physiol. 210, 897-917 (1970)

15) KurIYAMA, H.: The influence of potassium, sodium and chloride on the membrane potential of the smooth muscle of taenia coli. $J$. Physiol. 166, 15-28 (1963)

16) Dols. T. ANd Hetcher, O.: Lithium and brain adenylate cyclase. Lancet 1, 834-835 (1970)

17) Fori, J. ANd ValdeCASAS, F.G.: Effects of lithium on brain adenylate cyclase activity. Biochem. Pharmacol. 20, 2773-2779 (1971)

18) Palmer, G.C., Robison, G.A., Manian, A.A. And Sulser, F.: Modification by psychotropic drugs of the cyclic AMP response to norepinephrine in the rat brain in vitro. Psychopharmacol. 23, 201-211 (1972)

19) McIlwain, H., Harney, J.A. and Rodriguez, G.: Tetrodotoxin on sodium and other ions. of cerebral tissues, excited electrically and with glutamate. J. Neurochem. 16, 363-370 (1969)

20) Narahashi, T., Deguchi, T., URakawa, N. and OhKubo, Y.: Stabilization and rectification of muscle fiber membrane by tetrodotoxin. Am. J. Physiol. 198, 934-938 (1960)

21) Takata, M., Moore, J.W., KaO, C.Y. and Fuhrman, F.A.: Blockage of sodium conductance increase in lobster giant axon by tarichatoxin (tetrodotoxin). J. gen. Physiol. 49, 977988 (1966)

22) Okamoto, K. and Quastel, J.H.: Tetrodotoxin sensitive uptake of ions and water by slices of rat brain in vitro. Biochem. J. 120,37-47 (1970)

23) HerTZ, L. AND SCHOU, M.: Univalent cations and the respiration of brain cortex slices. Biochem. J. 85, 93-104 (1962)

24) PATON, W.D.M., VIZI, E.S. AND ZAR, M.A.: The mechanism of acetylcholine release from parasympathetic nerves. J. Physiol. 215, 819-848 (1971)

25) Bosakova, J. And Crane, R.K.: Studies on the mechanism of intestinal absorption of sugars. Biochim. Biophys. Acta 102, 436-441 (1965)

26) Shlittz, S.G., Curran, P.F., Chez, R.A. and Fuitz, R.E.: Alanine and sodium across. mucosal border of rabbit ileum. J. gen. Physiol. 50, 1241-1260 (1967)

27) Hodikix, A.L. AND KATZ, B.: The effect of sodium ions on the electrical activity of the giant axon of the squid. J. Physiol. 108, 37-77 (1949) 